\title{
HORIZONTAL DIRECT EFFECT OF THE CHARTER OF FUNDAMENTAL RIGHTS OF THE EU
}

\author{
SACHA PRECHAL 1 \\ Utrecht University \\ a.prechal@u.u.nl
}

Cómo citar/Citation

Prechal, S. (2020)

Horizontal direct effect of the Charter of Fundamental Rights of the EU.

Revista de Derecho Comunitario Europeo, 66, 407-426.

doi: https://doi.org/10.18042/cepc/rdce.66.04

\begin{abstract}
In a number of judgments rendered in 2018, the Court of Justice of the EU decided that the Charter of Fundamental Rights of the EU or at least some of its provisions might have horizontal direct effect. This contribution analyses these recent cases, puts them into perspective and reflects on the possible implications for the horizontal direct effect of the Charter. In particular, it will consider what the rationale is for accepting horizontal direct effect in this case-law, what lessons can be drawn for other Charter provisions and, finally, what relationship is emerging between EU directives and the provisions of the Charter.
\end{abstract}

\section{Keywords}

Horizontal direct effect; Charter of Fundamental Rights; Court of Justice of the EU; case-law.

1 Sacha Prechal is Judge at the Court of Justice of the EU and honorary professor of European law, Utrecht University. All views expressed in this contribution are strictly personal. The contribution was finalized in May 2020. 


\section{EL EFECTO DIRECTO HORIZONTAL DE LA CARTA DE DERECHOS FUNDAMENTALES DE LA UE}

\section{Resumen}

En una serie de sentencias dictadas en 2018, el Tribunal de Justicia de la UE decidió que la Carta de los Derechos Fundamentales de la UE o, al menos, algunas de sus disposiciones podrían tener un efecto directo horizontal. Esta contribución analiza estos casos recientes, los pone en perspectiva y reflexiona sobre las posibles implicaciones para el efecto directo horizontal de la Carta. En particular, considerará cuál es la razón para aceptar el efecto horizontal directo en esta jurisprudencia, qué lecciones se pueden extraer para otras disposiciones de la Carta y, finalmente, qué relación está surgiendo entre las directivas de la UE y las disposiciones de la Carta.

\section{Palabras clave}

Efecto directo horizontal; Carta de los Derechos Fundamentales; Tribunal de Justicia de la UE; jurisprudencia.

\section{L'EFFET DIRECT HORIZONTAL DE LA CHARTE DE DROIT FONDAMENTAUX DE L'UE}

\section{Résumé}

Dans un certain nombre d'arrêts rendus en 2018, la Cour de justice de l'UE a décidé que la Charte des droits fondamentaux de l'UE ou au moins certaines de ses dispositions pourraient avoir un effet direct horizontal. Cette contribution analyse ces cas récents, les met en perspective et réfléchit aux implications possibles pour l'effet direct horizontal de la Charte. En particulier, il examinera la justification de l'acceptation de l'effet direct horizontal dans cette jurisprudence, quelles leçons peuvent être tirées pour d'autres dispositions de la Charte et, enfin, quelle relation se dessine entre les directives de l'UE et les dispositions de la Charte.

\section{Mots clés}

Effet direct horizontal; Charte des droits fondamentaux; Cour de justice de l'UE; jurisprudence. 


\section{CONTENTS}

I. INTRODUCTION. II. A BRIEF RETROSPECT. III. THE CASES ON THE HORIZONTAL DIRECT EFFECT OF THE CHARTER. IV. WHAT ROLE FOR EU FUNDAMENTAL RIGHTS IN PRIVATE LAW RELATIONSHIPS? V. WHAT OUTLOOK FOR OTHER CHARTER PROVISIONS? VI. THE RELATIONSHIP BETWEEN DIRECTIVES AND CHARTER PROVISIONS. VII. CONCLUDING REMARKS. BIBLIOGRAPHY.

\section{INTRODUCTION}

The question of whether and how fundamental rights may produce effects in relations governed by private law, i.e. between individuals, is not entirely new, neither in European nor in national law. Rather, it is a sort of evergreen that has generated a wealth of literature as well as some - cautious - case law. ${ }^{2}$ In this sense, horizontal effects of the Charter of Fundamental rights of the EU (the Charter or CFR) is a part of a much broader debate about the role fundamental rights play or should play in society.

Like in domestic legal orders, in EU law horizontal effect can be realised in various ways. ${ }^{3}$ It may be achieved by interpreting national law, in particular national private law provisions or open textured national rules such as good faith and good morals, in a way that the result is in compliance with EU fundamental rights. Another option is to rely on the State's duty to protect the fundamental rights of private individuals. In Union law, there are only scarce examples of this approach. A version of this type of horizontal effect is the obligation of the state to protect the rights granted to private individuals by the Treaty free movement freedoms by application of the principle of loyal co-operation provided for in Art. 4(3) TEU and thus guarantee the effectiveness of free movement. ${ }^{4}$ Again another, closely related approach, is to hold

\footnotetext{
2 Cf. for example Oliver and Fedtke (2007), Barkhuysen and Lindenberg (2006).

3 Cf. for instance Seifert (2012), Safjan (2014).

4 In EU law context see Judgment of the Court of 9 December 1997, Commission of the European Communities v French Republic (Spanish strawberries), 265/95, EU:C:1997:595.
} 
that private parties are bound by fundamental rights in situations in which they are involved in the exercise of public law powers. ${ }^{5}$

These forms of indirect horizontal effect should be distinguished from horizontal direct effect. The latter is often understood as the possibility to rely directly before national courts on the fundamental rights provisions even in a horizontal context, i.e. in a dispute between private parties. An individual may rely on a fundamental rights provision for two different purposes. Either in order to establish directly, on the basis of that provision, the existence of a right and a correlating obligation for another private individual, or for purposes of legality review of applicable national norms and, potentially, the setting aside of these norms in the context of a dispute between private parties. There is, indeed, a qualitative difference between these two forms of 'relying upon'; only in the first situation, is the fundamental right provision an autonomous source of rights and obligations. In the second, a national rule which determines the content of the relationship between private parties cannot be applied for being incompatible with a fundamental right. However, in my opinion, what is at issue is that there is a change to legal relationships that modifies the rights and obligations of the parties. It does not matter whether this happens through direct application of EU law or by exclusion of applicable national rules that are incompatible. ${ }^{6}$

In a number of judgments rendered in $2018^{7}$ and after lively speculations in legal writing, ${ }^{8}$ the Court of Justice of the EU (CJEU) decided that the CFR or at least some of its provisions, may have horizontal direct effect.

5 This was basically an issue in A.G.M.-COS.MET. See Judgment of the Court of 17 April 2007, A.G.M.-COS.MET Srl v. Suomen valtio and Tarmo Lehtinen, 470/03, EU:C:2007:213.

6 In particular, in private law there is some debate about the proper definition of horizontal direct effect. The exclusion scenario is often considered as indirect horizontal effect. Cf. Aronstein (2019), at p. 25-26, with further references.

7 Judgment of the Court of 17 April 2018, Vera Egenberger v Evangelisches Werk für Diakonie und Entwicklung e.V. (Egenberger), 414/16, EU:C:2018:257; Judgment of the Court of 11 September 2018, IR v JQ (IR), 68/17, EU:C:2018:696; Judgment of the Court of 22 January 2019, Cresco Investigation GmbH v Markus Achatzi ( Cresco Investigation), 193/17, EU:C:2019:43; Judgment of the Court of 6 November 2018, Stadt Wuppertal v Maria Elisabeth Bauer and Volker Willmeroth v Martina Broßonn (Bauer\& Willmeroth), 569/16 and 570/16, EU:C:2018:871; Judgment of the Court of 6 November 2018, Max-Planck-Gesellschaft zur Förderung der Wissenschaften eV v Tetsuji Shimizu (Max-Planck), 684/16, EU:C:2018:874.

8 In particular after the Judgment of the Court of 15 January 2014, Association de médiation sociale v Union locale des syndicats CGT and Others (AMS), 176/12, EU:C:2014:2. Cf. Frantziou (2014) and Lazzerini (2014). 
In the present contribution I will, first, focus on this recent case law and, next, briefly reflect on the possible implications for the horizontal direct effect of the Charter. However, in order to put the topic in its proper context, I will start with a brief discussion of the horizontal direct effect of the TFEU provisions.

\section{A BRIEF RETROSPECT}

Accepting the horizontal direct effect of certain Charter provisions is, as such, nothing revolutionary. Rather, it fits into a line of cases in which horizontal direct effect was accepted of fundamental or quasi-fundamental rights that existed already before the CFR. These are the principle of equal pay of women and men, now laid down in Art. 157 TFEU, which developed from an economically inspired labour law standard to a fundamental right; ${ }^{9}$ and the fundamental - free movement - Treaty freedoms, including the prohibition of discrimination on the basis of nationality.

In Defrenne II the Court accepted the horizontal direct effect of Art. 119 EEC (now Art. 157 TFEU) despite the fact that that Art. was addressed to the Member States and arguably only the latter and not private individuals were bound by this provision. ${ }^{10}$ The Court held that ' ... since Article 119 is mandatory in nature, the prohibition on discrimination between men and women applies not only to the action of public authorities, but also extends to all agreements which are intended to regulate paid labour collectively, as well as to contracts between individuals'. ${ }^{11}$

While the free movement provisions are not directed solely at the Member States, the general understanding was, in contrast to the competition rules, that those provisions were primarily drafted for the Member States and were not directed at private individuals. Nevertheless, in its case law the Court gradually accepted that the free movement provisions might also have horizontal direct effect. This case law covers a number of situations. In the first place, there are cases in which rules of 'non-public' sports organisations ${ }^{12}$

9 According to the Court Article $141 \mathrm{EC}$ (now Article 157 TFEU) '... constitutes the expression of a fundamental human right'. See Judgment of the Court of 10 February 2000, Deutsche Telekom AG v Lilli Schröder, 50/96, EU:C:2000:72, para. 56.

10 The former Advocate General VerLoren van Themaat called the Defrenne judgment a 'saltation'. See VerLoren van Themaat (1977).

11 Judgment of the Court of 8 April 1976, Gabrielle Defrenne v Société anonyme belge de navigation aérienne Sabena (Defrenne II), 43/75, EU:C:1976:56, para. 39.

12 To start with Judgment of the Court of 12 December 1974, B.N.O. Walrave and L.J.N. Koch v Association Union cycliste internationale, Koninklijke Nederlandsche 
or other professional associations ${ }^{13}$ were at issue. Actions of these entities that are aimed at regulating gainful employment in a collective manner or that are intended to regulate, collectively, the work of self-employed persons and the provision of services, are subject to the obligations flowing from the free movement provisions. The main reasons behind this finding is that the free movement provisions would not function effectively if private organisations were allowed to create or maintain obstacles that governments are not allowed to create or maintain. ${ }^{14}$ Second, and closely related, is the situation in which a non-state actor is in a position of dominance. This aspect was clearly brought to the fore in the judgment in Ferlini. The CJEU pointed out that ' $\ldots$ the first paragraph of Article 6 of the Treaty [now Article 18 TFEU] also applies in cases where a group or organisation such as the EHL exercises a certain power over individuals and is in a position to impose on them conditions which adversely affect the exercise of the fundamental freedoms guaranteed under the Treaty. ${ }^{15}$

The judgment in Viking, which concerned, inter alia, collective action aimed at forcing foreign employers to sign or apply a certain collective agreement, suggests a synthesis between the free movement approach and the 'Defrenne II -avenue'. The Court found that Art. 43 EC [now Art. 49 TFEU] could be relied upon against the (federation of) trade unions, mainly for two reasons. First, non-public law organisations are not allowed, in the context of their legal autonomy, to neutralise the prohibition on obstacles by restricting free movement instead of the government. ${ }^{16}$ Second, private individuals can derive rights from provisions which are formally directed at

Wielren Unie and Federación Española Ciclismo (Walrave and Koch), 36/4, EU:C: 1974:140.

13 Judgment of the Court of 19 February 2002, J. C. J. Wouters, J. W. Savelbergh and Price Waterhouse Belastingadviseurs BV v Algemene Raad van de Nederlandse Orde van Advocaten, intervener: Raad van de Balies van de Europese Gemeenschap (Wouters), 309/99, EU:C:2002:98 This case related to a regulation of the Dutch Bar Association.

14 Judgment of the Court of 15 December 1995, Union royale belge des sociétés de football association ASBL v Jean-Marc Bosman, Royal club liégeois SA v Jean-Marc Bosman and others and Union des associations européennes de football (UEFA) $\mathrm{v}$ Jean-Marc Bosman (Bosman), 415/93, EU:C:1995:463, paras. 82-83.

15 Judgment of the Court of 3 October 2000, Angelo Ferlini v Centre hospitalier de Luxembourg (Ferlini), 411/98, EU:C:2000:530, para. 50. The EHL stands for the Entente des Hôpitaux Luxembourgeois (Luxembourg Hospitals Group).

16 Judgment of the Court of 11 December 2007, International Transport Workers' Federation and Finnish Seamen's Union v Viking Line ABP and OÜ Viking Line Eesti (Viking) 438/05, EU:C:2007:772, para. 57. 
the Member States and, according to the Court, '...the prohibition on prejudicing a fundamental freedom laid down in a provision of the Treaty that is mandatory in nature, applies in particular to all agreements intended to regulate paid labour collectively'. ${ }^{17}$ Since Art. 49 TFEU contains a fundamental freedom, these considerations also apply to that provision. ${ }^{18}$

Finally, in Angonese there is a clear hint that also private persons acting individually are under the obligation to respect the Treaty freedoms and that these provisions can be invoked against these individuals. ${ }^{19}$ In Angonese the Court recalled that according to its judgment in Defrenne II, ' $\ldots$ the prohibition of discrimination applied equally to all agreements intended to regulate paid labour collectively, as well as to contracts between individuals'. Next, it continued by saying that ' $[\mathrm{s}] \mathrm{uch}$ considerations must, a fortiori, be applicable to Article 48 of the Treaty [now 45 TFEU], which lays down a fundamental freedom and which constitutes a specific application of the general prohibition of discrimination contained in Article 6 of the EC Treaty ... [now Article 18 TFEU]. ${ }^{20}$

In brief, it would seem that there are a number of situations in which the Court accepts horizontal direct effect of the FEU Treaty: ${ }^{21}$ (quasi-) fundamental rights provisions which are of mandatory nature, in particular the prohibition of discrimination, may apply in relationships between individuals; the free movement rules and prohibition of discrimination apply to private law rules which aim at regulating gainful employment and the provision of services in a collective manner; similarly they apply in a situation of dominance, i.e. where certain actors have power over individuals and are in a position to impose their will unilaterally.

These various tests are applied in parallel to each other or are even combined in one single judgment. The judgment in Viking, mentioned above, is an example of this. The more recent judgment in Biff combined both the

17 Ibid., para. 58.

18 Ibid., para.59. For a more detailed discussion, see Prechal and de Vries (2009), in particular Sections 3 and 4.

19 Judgment of the Court of 6 June 2000, Roman Angonese v Cassa di Risparmio di Bolzano SpA (Angonese), 281/98, EU:C:2000:296.

20 Ibid., para. 35, confirmed in Judgment of the Court of 17 July 2008, Andrea Raccanelli v Max-Planck-Gesellschaft zur Förderung der Wissenschaften eV., 94/07, EU:C:2008:425.

21 Horizontal direct effect of Articles 101 and 102 are as such not problematic because they contain prohibitions addressed to private parties. 
collective regulation approach with the dominance test in relation to Art. 18 and 21 TFEU. ${ }^{22}$

\section{THE CASES ON THE HORIZONTAL DIRECT EFFECT OF THE CHARTER}

The cases, all decided in 2018, concern horizontal direct effect of Art. 21 CFR, more particularly the prohibition of discrimination on grounds of religion, Art. 47, the right to effective judicial protection, and Art. 31 (2) CFR, the right to paid annual leave.

The religion discrimination cases concerned alleged discrimination by private employers. In the first case, Ms Egenberger applied for a job with Evangelisches Werk für Diakonie und Entwicklung, a private organisation which pursues charitable, benevolent and religious purposes. The job entailed the preparation of a report on Germany's compliance with the United Nations International Convention on the Elimination of All Forms of Racial Discrimination. Ms Egenberger, of no denomination, was shortlisted but eventually not invited for an interview, apparently because she did not belong to a Protestant church. ${ }^{23}$

The second case concerned JQ, a doctor in a hospital run by IR, a limited liability company which carried out the work of Caritas (the international confederation of Catholic charitable organisations). JQ was a Roman Catholic but he divorced and remarried in a civil ceremony without his previous marriage being annulled. For this reason, he was dismissed. However, the hospital did not dismiss another employee in a comparable situation but who was of Protestant faith. ${ }^{24}$

The issue in the third case was the very fact that in Austria, Good Friday is a paid public holiday only for members of 4 specific churches, namely the Evangelical Churches of the Augsburg and Helvetic Confessions, the Old Catholic Church and the United Methodist Church. If a member of one of those churches works on Good Friday, he or she is entitled to additional pay. Mr. Achatzi, not a member of any of the churches in question, worked

22 Judgment of the Court of 13 June 2019, TopFit e.V. and Daniele Biffi v Deutscher Leichtathletikverband e.V. (Biffi), 22/18, EU:C:2019:497. The case concerned rules of a national sports association which govern the access of EU citizens (amateur athletes) to sports competitions.

23

Egenberger, n. 7.

24 IR, n. 7. 
on Good Friday and claimed extra pay from Cresco Investigations, a private detective agency. He argued that he suffered discrimination by being denied public holiday pay. ${ }^{25}$

The substance of the cases was dealt with under Directive 2000/78. ${ }^{26}$ However, since provisions of a directive have no horizontal direct effect and it was not certain whether consistent interpretation of national law was possible, the Court turned to Art. 21 CFR.

The Court pointed out that the principle of equal treatment in the field of employment and occupation originates in various international instruments and the constitutional traditions common to the Member States and is not established, as such, by the Directive. Moreover, the prohibition of discrimination on grounds of religion is mandatory as a general principle of EU law and is laid down in Art. 21 CFR. That provision is sufficient in itself to confer on individuals a right, which they may rely on as such in disputes between them. Finally, the Court observed that as regards its mandatory effect, Art. 21 CFR is no different, in principle, from the various provisions of the founding Treaties prohibiting discrimination on other grounds and these provisions apply also where discrimination has origin in contractual relationships. ${ }^{27}$ For these reasons, if consistent interpretation of national law is not possible, the referring court must ensure judicial protection of the right conferred by Art. $21 \mathrm{CFR}$ and guarantee the full effectiveness of that Article even in disputes between individuals. ${ }^{28}$

With a less detailed reasoning, the Court further decided on the horizontal direct effect of Art. 47 CFR, in combination with Art. 21 CFR. The Court held that Art. 47 is sufficient in itself and does not need to be made more specific by provisions of EU or national law to confer on individuals a right which they may rely on as such and that the national court must ensure the judicial protection for individuals flowing from Arts. 21 and 47 CFR. ${ }^{29}$

The reason for taking also Art. 47 CFR on board was that the case at issue required striking a balance between the right of autonomy of churches and other organisations whose ethos is based on religion or belief, on the one hand, and, on the other hand, the right of individuals not to be discriminated

25 Cresco Investigation, n. 7.

26 Council Directive 2000/78/EC of 27 November 2000 establishing a general framework for equal treatment in employment and occupation (OJ $2000 \mathrm{~L} \mathrm{303,} \mathrm{p.} \mathrm{16).}$

27 The Court makes here an explicit reference to the judgments in Defrenne II, Angonese, Ferlini and Viking, discussed in the previous Section.

28 Egenberger, n. 7, paras. 75-77.

29 Ibid., paras. 78 and 79. 
against on grounds of religion or belief. While, as a matter of German law, the review by the courts was a very restrained one using the so-called 'plausibility control', under EU law the judicial review must be 'effective'. When an employer argues that for the activities to be performed religion constitutes a genuine, legitimate and justified occupational requirement, having regard to the ethos of the church or organisation, such an assertion must be subject to effective judicial review. In such a review, it must be ensured that the criteria set out in Art. 4(2) of Directive 2000/78 are satisfied in the particular case. ${ }^{30}$

At the origin of the cases on the right to paid annual leave were again two labour law disputes. In Willmeroth, the employer did not want to pay a compensation for paid annual leave that was not taken because, under national law, the entitlement to paid annual leave is lost where the employment ends by death of the worker. The consequence was that the widow of the diseased employee was not entitled to any payment. In the Max-Planck case, Mr. Shimizu claimed, at the end of his contract, an allowance instead of a number of days of his paid annual leave, which he had not taken. However, Max-Planck refused the payment because, according to them, the entitlement to paid annual leave had lapsed as a matter of national law.

Both cases concerned, in the first place, an interpretation of the content of Art. 7 of the Working Time Directive ${ }^{31}$ and Art. 31(2) CFR. As to the effects these provisions may produce, since directives cannot be relied upon against private individuals and consistent interpretation was, according to the referring court, not possible, the Court addressed the question of the horizontal direct effect of the Charter provision. ${ }^{32}$

The Court recalled that the right to paid annual leave is an essential principle of EU social law, is mandatory in nature and is based on various pre-existing EU or international instruments, such as the Community Charter of the Fundamental Social Rights of Workers, the European Social Charter and

30 Art. 4(2) allows for national legislation '...pursuant to which, in the case of occupational activities within churches and other public or private organisations the ethos of which is based on religion or belief, a difference of treatment based on a person's religion or belief shall not constitute discrimination where, by reason of the nature of these activities or of the context in which they are carried out, a person's religion or belief constitute a genuine, legitimate and justified occupational requirement, having regard to the organisation's ethos. [...].'

31 Directive 2003/88/EC of the European Parliament and of the Council of 4 November 2003 concerning certain aspects of the organisation of working time (OJ 2003 L 299, p. 9)

32 Art. 31 (2) CFR provides 'Every worker has the right ... to an annual period of paid leave.' 
the Convention No 132 of the International Labour Organisation. Therefore, it is not, as such, established by the Working Time Directive. Next, the Court emphasised the mandatory terms of the provision, which does not refer to the fact that the right is guaranteed in 'the cases and under the conditions provided for by Union law and national laws and practices', as does for instance Art. 27 CFR. ${ }^{33}$ The Court considered that the right to a period of paid annual leave, as affirmed in Art. 31(2) CFR, is, as regards its very existence, both mandatory and unconditional in nature. There is no need to elaborate the right in that respect by other provisions of Union or national law. Such provisions are only required in order to specify the exact duration of the leave and the conditions for the exercise of that right. Therefore, Art. 31(2) CFR is sufficient in itself to confer on workers a right that they may actually rely on in disputes between them and their employer.

The Court also considered an argument that was often brought to the fore in order to deny horizontal direct effect of the Charter provisions: according to Art. 51 (1) CFR, the Charter is addressed to the EU institutions, bodies, offices and agencies and to the Member States when they are implementing EU law. That, however, according to the Court, does not systematically preclude the possibility that individuals may be directly required to comply with certain provisions of the Charter. As the case law makes clear, the fact that certain provisions of primary law are addressed principally to the Member States does not preclude their application to relations between individuals. In particular, in Egenberger, the Court accepted that individuals may rely on Art. 21 (1) CFR in a dispute with another individual without 51(1) CFR preventing it. Finally, the right of every worker to annual paid leave entails by its very nature a corresponding obligation on the employer, which is to grant such periods of paid leave.

\section{WHAT ROLE FOR EU FUNDAMENTAL RIGHTS IN PRIVATE LAW RELATIONSHIPS?}

As was mentioned in Section II, one of the rationales for accepting horizontal direct effect of the Treaty freedoms was 'integration driven': the free movement provisions would not function effectively if private organisations

33 In case $A M S$, n. 8, the reference to cases and conditions 'provided for by Union law and national laws and practices' was the reason for not accepting direct effect of Art. 27 CFR. In other terms, this provision, in order to be fully operational, needed further elaboration in European Union or national law. See further also Section V. 
were allowed to create or maintain obstacles that governments are not allowed to create or maintain. What is the rationale of the cases discussed above? A few observations can be made in this respect.

First, as was already set out, the Court set aside the argument based on Art. 51(1). Apart from the consideration that, according to the Court, the Member States being formally the addressees of the Charter provisions does not preclude their application between individuals, one may wonder whether that provision was intended to deal with the problem of 'who are the addressees?' and, in the wake of that, the issue of possible horizontal direct effect. In any case, this is not what the travaux préparatoires of the Charter or the Explanations relating to the Charter would suggest. ${ }^{34}$ Art. 51(1) concerns rather the question of when the Charter is applicable in the Member States and aims at safeguarding that the powers of the Union are not extended beyond those which the Union has under the Treaties. ${ }^{35}$

Second, although, initially, fundamental rights were conceived as protection against the State and therefore only the State was bound by fundamental rights provisions, due to profound changes in the society there has also been a change in perception about the question regarding who is under the obligation to respect fundamental rights. The idea that there is a need to protect individuals against 'omnipotent states' only, while in private relationships the behaviour rests on free will has long worn off. The public - private divide is changing, while the need for protection remains. Various public functions are privatised, public responsibilities are either 'contracted out' or transferred to private parties. New decision-making fora where the state does not directly interfere, in the context of, in particular, sharing or on demand economy are booming. Both 'consumers' and persons that would normally be considered employees are dependent on these. Briefly put, there is an important shift of power to the private sector. In such a context, the need for an adequate and different protection of fundamental rights has changed too. Horizontal direct effect of fundamental rights is one of the possible means to realize such a protection.

Third, fundamental rights are frequently also perceived as expression of values that underlie the entire legal order, public and private; they are so elementary that they must be applicable in both private and public law

34 Cf. the opinion of Advocate General Cruz Villalón, $A M S$, 176/12, EU:C:2013:491, at point 31.

35 Basically it aims at avoiding the CFR from becoming a self-standing standard of fundamental rights protection and requires that there always be a link with the scope of application of EU law. See Judgment of the Court of 26 February 2013, Aklagaren v Hans Åkerberg Fransson (Akerberg Fransson), 617/10, EU:C:2013:105. 
relationships. ${ }^{36}$ This may explain why fundamental rights are often couched in general terms, without mentioning the duty bearers of these rights. It is striking that in the Court's case law discussed above, much emphasis is put on the mandatory, and in the case of the annual leave also the essential, nature of the fundamental rights at issue. Similarly, the very fact that the rights form an integral part of the general principles of law whose observance the Court ensures and that the rights have their basis also in various pre-existing international or constitutional instruments is strongly put to the fore. These considerations would indeed point in the direction that, according to the Court, in EU law fundamental rights are essential values permeating the entire EU legal order and therefore may produce, under certain conditions, horizontal direct effect.

\section{WHAT OUTLOOK FOR OTHER CHARTER PROVISIONS?}

The cases decided until now concerned Art. 21, 31(2), 47 and 27 CFR. In relation to the first three provisions horizontal direct effect has been accepted, while in the case of Art. 27 it has been denied. ${ }^{37}$ What lessons can be drawn for other provisions of the Charter?

It would seem, in the first place, that the nature of the provision matters. The provision at issue should be capable, as far as its content is concerned, of playing a role in relationships between private individuals. In particular, the very nature of the right should be that there is a corresponding obligation of another private party. So far, the cases decided concerned obligations of employers. In Willmeroth and Max-Planck the Court pointed out explicitly that the right of every worker to annual paid leave entails by its very nature a corresponding obligation on the employer. ${ }^{38}$ However, there are, obviously, various other provisions that may eventually impose obligations upon individuals. This is not only true for rights such as respect for private and family life, freedom of expression and information and freedom to conduct a business, which includes freedom of contract, but might also include provisions like the right to the integrity of the person, prohibition of torture and inhuman or degrading treatment and prohibition of slavery. ${ }^{39}$

36 De Mol (2011), at 112, with further references.

37 AMS, n. 8.

38 Bauer\& Willmeroth, n. 6, para. 90 and Max-Planck, n. 7, para. 79.

39 This indeed gives rise to complex questions about free consent of the parties involved and the limits of private law party autonomy. Arguably, interference in private auto- 
In the second place, one may wonder how to assess the Courts emphasis of the rights at issue being a part of general principles of law and the very fact that they can be traced back to pre-existing fundamental rights instruments. Is this one of the conditions for a provision having horizontal direct effect? I would not think so. As was already discussed above, these considerations form rather the foundations of the court's argument on why the fundamental rights at issue may have horizontal direct effect. In any case, many of the rights guaranteed in the Charter have their origin in constitutional traditions, other international law instruments, in particular the European Convention of Human Rights and the European Social Charter, or have been recognized by the Court as general principles of law which the Court protects. ${ }^{40}$

As the case law stands now, the crucial condition is that the provision at issue must be sufficient in itself to confer a right. This is the case when a provision is mandatory, in the sense that parties cannot derogate from it, for instance by contract, and when it is unconditional. This means that no further elaboration is necessary for its application. Unsurprisingly, the latter requirement coincides with the requirements for direct effect: provisions that are conditional in the sense that they need to be elaborated further before becoming a sufficiently operational standard to be applied by a court, will lack direct effect. ${ }^{41}$ A provision that has no direct effect cannot be applied at all, neither in vertical nor in horizontal situations. What is different from standard case law on direct effect is the fact that the provision of the Charter must confer a right.

nomy is fully acceptable in situations where one party is in a subordinated position and the other party is able to impose conditions which adversely affect the exercise of fundamental rights. Cf. in this respect for instance Ferlini, n. 15, briefly discussed above, in Section II.

40 See, for instance, in relation to the right to privacy Judgment of the Court 13 May 2014, Google Spain SL and Google Inc. v Agencia Española de Protección de Datos (AEPD) and Mario Costeja González, 131/12, EU:C:2014:317,para. 68 and in relation to the right to integrity of the person Judgment of the Court of 9 October 2001, Kingdom of the Netherlands v European Parliament and Council of the European Union, 377/98, EU:C:2001:523, paras. 78-79.

41 Cf. the opinion of Advocate General Van Gerven, H. J. Banks \& Co. Ltd v British Coal Corporation, 128/92, EU:C:1993:860, at page 1237: ' $\ldots$ provided and in so far as a provision of Community law is sufficiently operational in itself to be applied by a court, it has direct effect. The clarity, precision, unconditional nature, completeness or perfection of the rule and its lack of dependence on discretionary implementing measures are in that respect merely aspects of one and the same characteristic feature which that rule must exhibit, namely it must be capable of being applied by a court to a specific case.' 
In the cases on paid annual leave the Court emphasised that unlike Art. 27 CFR, Art. 31 (2) CFR does not refer to 'the cases and ... conditions provided for by Union law and national laws and practices'. In $A M S$ it was decided that Art. 27 CFR needed further elaboration first before being fully effective. For that reason, Art. 27 had no direct effect. Does this mean that all the provisions that refer to EU implementing measures and/or national legislation or practices are not sufficiently precise and unconditional to have direct effect and a fortiori to confer a right on individuals? In any case, from the judgment in Viking it would transpire that the right to take collective action is a fully-fledged right, despite the fact that Art. 28 CFR refers to 'Union law and national laws and practices'. ${ }^{42}$ Moreover, there are provisions that do not refer to EU implementing measures and/or national legislation or practices but are, nevertheless, not self-sufficient. As the Court pointed out, in so far as Art. 31(2) CFR states the right of every worker 'to limitation of maximum working hours, to daily and weekly rest periods', these aspects need elaboration through additional legal instruments. ${ }^{43}$

Finally, there is the notorious distinction between rights and principles, laid down in Art. 52(5) CFR. According to this paragraph, there are provisions that do not confer a right but, nevertheless, may be used as an aid to interpretation or as a standard for judicial review of implementing measures. These latter provisions are called principles. ${ }^{44}$ What if a provision does not confer a right - so is a 'principle' - but is used in a dispute between two private parties in order to review the legality of national implementing legislation? For the time being, the $A M S$ judgment suggests a negative answer: such a provision cannot be relied upon in a dispute between individuals. This is because not only Art. 27 was not directly effective as such, but, as the Court emphasised, in contrast to the judgment in Kücükdeveci, that Article does not confer an individual right. ${ }^{45}$ The emphasis in the judgments under discussion in this article on the existence of a right points in the same direction.

This debate should not be mixed up with another issue, namely what horizontal direct effect is about, referred to in the Introduction: does it cover the setting aside of national rules in disputes between individuals or does this notion refer only to situations where Charter provisions constitute a direct source of rights and obligations? The cases discussed did indeed concern the setting aside scenario in the first place. However, in Cresco, the employer was

\footnotetext{
Viking, n. 16, paras. 43-44.

Bauer\& Willmeroth, n. 7, para. 85.

Cf. Lock (2019), Prechal (2014).

$A M S$, n. 8, para. 47.
} 
in principle obliged to pay the extra salary for Good Friday, on the basis of the principle of equal treatment. ${ }^{46}$ In Willmeroth the national court had to disapply national legislation that deprived a worker retroactively of his annual paid leave acquired before his death. The Court added that employers could not rely on that legislation in order to avoid the payment. ${ }^{47}$ In other terms, the Court confirmed that there exists an obligation for the employers.

\section{THE RELATIONSHIP BETWEEN DIRECTIVES AND CHARTER PROVISIONS}

Obviously, for the question of horizontal direct effect of the Charter provisions, the Charter must be applicable. According to Art. 51(1) CFR, the Charter is applicable in the Member States when the latter are implementing Union law'. ${ }^{48}$ In the cases under discussion in the present contribution, the implementation of Directive 2003/88 or Directive 2000/78 pulled the Member State action into the scope of EU law and rendered the Charter applicable. ${ }^{49}$ Both directives elaborate in fact the respective fundamental rights at issue. This begs the question of whether accepting horizontal direct effect of the fundamental right provisions boils down to circumventing the absence of horizontal direct effect of directives. This was argued by many after the judgemnt in Mangold and, in particular, after the judgment in Kücükdeveci. ${ }^{50}$ In Kücükdeveci the Court held that the the principle of non-discrimination on grounds of age as given concrete expression by Directive 2000/78, must be interpreted as precluding, national legislation [that was incompatible with that principle] $]^{51}$ and the court had to set aside the provisions of this legislation, also in disputes between individuals. ${ }^{52}$ This 'combination-approach' - the general principle as given expression by a directive - was extensively

\footnotetext{
46 Cresco Investigation, n. 7, para. 86.

47 Bauer\& Willmeroth, n. 7, para. 86.

48 Akerberg Fransson, n. 35, and its progeny.

49 Egenberger, n. 7, para. 49 and Bauer\& Willmeroth, n. 7, para. 53.

50 Judgment of the Court of 22 November 2005, Werner Mangold v Rüdiger Helm (Mangold) 144/04, EU:C:2005:709, Judgment of the Court of 19 January 2010, Seda Kücükdeveci v Swedex GmbH \& Co. KG. (Kücükdeveci), 555/07, EU:C:2010:21. Cf. for instance De Mol (2011); for an assessment of the debate see also Dougan (2011).

51 Kücükdeveci, n. 50, para. 43.

52 Cf. to that effect ibid., para. 56.
} 
criticized and even dismissed by the Danish Supreme Court in the DI case. ${ }^{53}$ The Højesteret refused to set aside national law provisions that were contrary not only to Directive 2000/78 but also to the general principle of non-discrimination on grounds of age. Since this unwritten principle had no clear legal basis in the Treaty and was not covered by the Danish Accession Act, it could not override national law. ${ }^{54}$

Is this different under the case law of horizontal direct effect of the Charter provisions? And what about the risk that the content of the directive will inform the interpretation of the fundamental right at issue? ${ }^{55}$

Since the judgment in $A M S$ and as confirmed in subsequent case law, the directive still triggers the application of the Charter. However, as far as the horizontal direct effect of a provision of the Charter is concerned, this provision must satisfy a self-standing test: the provision must be sufficient in itself to confer a right. If there were need to give substance to a Charter provision while relying on a corresponding directive, the provision would not be sufficient in itself. This is exemplified by the judgment in Willmeroth. In that case, the Court distinguished between the very existence of the right to a period of paid annual leave - this was self-sufficient - and the need for elaboration by other provisions of Union or national law for the purpose of the exact duration of the leave and the conditions for the exercise of that right.

From this one should distinguish reliance on legislative guidance that may play a role when striking a balance between competing fundamental rights, as happened in Egenberger. As was already observed above, ${ }^{56}$ one of the issues in the case was the fair balance between two fundamental rights: the right of autonomy of churches and other organisations whose ethos is based on religion or belief, on the one hand, and, on the other hand, the right of workers not to be discriminated against on grounds of religion or belief. To that end, Art. 4(2) of Directive 2000/78 gives the criteria to be taken into account in the balancing exercise. The very fact that a court may be called upon to balance fundamental rights and in that context verify whether the principle of proportionality is complied with does, first, not affect the horizontal direct effect of the provision at issue. ${ }^{57}$ Second, in this balancing

53 Judgment of the Court of 19 April 2016, Dansk Industri (DI), acting on behalf of Ajos A/S v Estate of Karsten Eigil Rasmussen (DI), 441/14, EU:C:2016:278.

54 Cf. Šadl and Mair (2017).

55 Cf. the opinion of Advocate General Bobek, Cresco Investigation, EU:C:2018:614, points 142-144.

56 Section III.

57 Egenberger, n. 7, para. 80. 
exercise, the court will have to take into consideration the balance struck between the interests concerned by the EU legislature, in the concrete case at hand in Directive 2000/78.58

In other terms, when deciding a possible justification under Art. 52 (1) CFR or, arguably, an objective justification in the context of the prohibition of discrimination, the courts should use the legislative guidance, if any, provided in a directive and that even in cases of horizontal direct effect of a Charter provision.

\section{CONCLUDING REMARKS}

Horizontal direct effect of Union fundamental rights did not fall from the sky. Its origins go back to the mid-seventies of the last century when the acceptance of horizontal direct effect had, at least partly, a different rationale. Nevertheless, the recent case law of the Court joins the older developments. With the entry into force of the Charter, the question of horizontal direct effect of fundamental rights gained new momentum. Interestingly, with this entry into force, some of the older EC/EU Treaty provisions obtained an official fundamental rights status.

The central requirement in the case law on the horizontal direct effect of the Charter is that the provision concerned must be sufficient in itself to confer a right, no further elaboration or specification being necessary for its application. Although at first blush this requirement may seem clear and simple, its concrete application raises a number of unexplored questions. These questions concern, in particular, the relevance of the reference to EU implementing measures and/or national legislation or practices and, partly in the wake of that, the distinction between rights and principles, an issue far from clarified in the case law. Similarly, the application of the requirement will touch upon delicate dividing lines between provisions that are aimed at conferring rights $v$. provisions which do confer rights, and the distinction of whether the very existence of the right is at stake or rather its exercise, subjected to further conditions. This gives, indeed, food for thought, for further research as well as, no doubt, for new case law.

For the time being, it would seem that there are only a few provisions of the Charter capable of satisfying the requirements for horizontal direct effect. In any case, it should be recalled that an adequate protection of fundamental rights between individuals is the responsibility of the legislator and

58 Ibid., para. 81. 
enforcement state authorities in the first place. This however does not detract from the importance of the Court's recent findings.

\section{Bibliography}

Aronstein I. (2019). Remedies for Infringements of EU Law in Legal Relationships between Private Parties. Deventer: Wolters Kluwer.

Barkhuysen, T. and Lindenberg, S. (eds.) (2006). Constitutionalisation of Private Law. Leiden: Matinus Nijhoff Publishers. Available at: https://doi.org/10.1163/ ej.9789004148529.i-136.

Dougan, M. (2011). In Defence of Mangold?. In A. Arnull et. al. (eds), A Constitutional Order of States?, Essays in EU Law in Honour of Allan Dashwood (219244). Oxford: Hart Publishing.

Frantziou, E. (2014). Case C-176/12 Association de Médiation Sociale: Some Reflections on the Horizontal Effect of the Charter and the Reach of Fundamental Employment Rights in the European Union. European Constitutional Law Review, 10 (2), 332-348. Available at: https://doi.org/10.1017/S1574019614001205.

Lazzerini, N. (2014). (Some of) the fundamental rights granted by the Charter may be a source of obligations for private parties: AMS. Common Market Law Review, 51 (3), 907-934.

Lock, T. (2019). Rights and Principles in the EU Charter of Fundamental Rights. Common Market Law Review, 56 (5), 1201-1226.

De Mol, M. (2011). The Novel Approach of the CJEU on the Horizontal Direct Effect of the EU Principle of Non-Discrimination. Maastricht Journal of European and Comparative Law, 18 (1-2), 109-135. Available at: https://doi. org/10.1177/1023263X1101800106.

Oliver, D. and Fedkte, F. (eds.) (2007). Human Rights and the Private Sphere - A Comparative Study. London: Routledge-Cavendish.

Prechal, S. (2014). "Article 52(5)". In Steve Peers, Tamara Hervey, Jeff Kenner and Angela Ward (eds.), The EU Charter of Fundamental Rights - A Commentary (pp. 1505-1511). Oxford: Hart Publishing, Oxford.

Prechal, S. and de Vries, S. (2009). Seamless web of judicial protection in the internal market?. European Law Review, 34 (1), 5-24.

Seifert, A. (2012). L'effet horizontal des droits fondamentaux. Quelques réflexions de droit européen et de droit comparé. Revue trimestrielle de droit européen, 4, 801-827.

Šadl, U. and Mair, S. (2017). Mutual Disempowerment: Case C-441/14 Dansk Industri, acting on behalf of Ajos A/S $v$ Estate of Karsten Eigil Rasmussen and Case no. 15/2014 Dansk Industri (DI) acting for Ajos A/S v The estate left by A. European Constitutional Law Review, 13 (2), 347-368. Available at: https://doi. org/10.1017/S1574019617000116. 
Safjan, M. (2014). The Horizontal Effect of Fundamental Rights in Private Law On Actors, Vectors, and Factors of Influence. In K. Purmhagen and P. Rott (eds.). Varieties of European Economic Law and Regulation, Liber Amicorum for Hans Micklitz. New York: Springer. Available at: https://doi.org/10.1007/9783-319-04903-8_7.

VerLoren van Themaat, P. (1977). Nogmaals het Defrenne-arrest: een juiste sprongmutatie in de rechtspraak?. Sociaal-economische wetgeving, 25 (2), 90-96. 